\title{
Effects of Thermal Aging on Microstructure and Corrosion Resistance of AISI 317L Steel Weld Metal in the FSW Process
}

\author{
Humberto Nogueira Farneze $e^{a, b, *}$, Sérgio Souto Maior Tavares ${ }^{a}$, Juan Manuel Pardal ${ }^{a}$, \\ Antônio José Ramirez Londoño ${ }^{c}$, Victor Ferrinho Pereirac, Cássio Barbosa ${ }^{d}$ \\ ${ }^{a}$ Programa de Pós-graduação em Engenharia Mecânica, Universidade Federal Fluminense - UFF, \\ CEP 24210-240, Niterói, RJ, Brazil \\ ${ }^{b}$ Centro Federal de Educação Tecnológica de Itaguai - CEFET/RJ, CEP 23810-000, Itaguaí, RJ, Brazil \\ ${ }^{c}$ Brazilian Nanotechnology National Laboratory - LNNANO, CEP 13083-970, Campinas, SP, Brazil \\ ${ }^{d}$ Instituto Nacional de Tecnologia-INT/MCTI, CEP 20081-312, Rio de Janeiro, RJ, Brazil
}

Received: November 10, 2014; Revised: March 8, 2015

\begin{abstract}
The AISI $317 \mathrm{~L}$ grade is an austenitic stainless steel with high Mo content ( $3.0 \mathrm{wt} \% \mathrm{~min}$.). Due to the higher pitting resistance, this grade has replaced AISI 316L steel in many applications where the corrosion resistance is a critical property. However, the high Mo can induce phase transformations in high temperature services. In modern oil refinaries and petrochemical industries AISI $317 \mathrm{~L}$ has been selected for temperatures as high as $550^{\circ} \mathrm{C}$. The goal of this work was to analyze the microstructural evolution and corrosion resistance of base and weld metal of AISI 317L stainless steel. The welded joints were produced by friction stir welding (FSW). The effect of prolonged exposure at $550{ }^{\circ} \mathrm{C}$ was investigated in specimens aged for $200 \mathrm{~h}, 300 \mathrm{~h}$ and $400 \mathrm{~h}$. After each aging treatment microstructural characterization was performed by scanning electron microscopy (SEM). Double loop electrochemical polarization reactivation tests (DL-EPR) were performed to evaluate the degree of sensitization of the samples. The results indicated that the increase of the exposure time at $550{ }^{\circ} \mathrm{C}$ promotes the formation of intermetallic phases, which causes corrosion decay of the weld metal.
\end{abstract}

Keywords: AISI $317 L$, austenitic stainless steel, FSW, corrosion resistance, DL-EPR

\section{Introduction}

The optimization of the structural integrity of the equipment applied in the petrochemical industry motivates the analysis and validation of alternative materials and welding processes, seeking to ensure better metallurgical properties under severe service conditions.

Austenitic stainless steels are usually selected to high temperature services due to the high creep and oxidation resistance. However, microstructural changes may take place during service. For instance, AISI 304 and 304H steels undergo sensitization due to $\mathrm{Cr}_{23} \mathrm{C}_{6}$ precipitation between 450 and $850^{\circ} \mathrm{C}$. Despite of this, " $\mathrm{H}$ " grades are often selected for high temperature services because $\mathrm{Cr}$ carbides enhance creep resistance ${ }^{2}$.

If sensitization by chromium carbide precipitation is considered a problem in services were corrosion resistance must be maintained, $\mathrm{Nb}$ or Ti-stabilized steels can be used (grades AISI 347 or AISI 321). However, these steels are susceptible to sigma $(\sigma)$ phase formation in long term aging ${ }^{3-4}$.

Recently, due to the demand of higher pitting corrosion resistance materials, AISI 317L steel with 3-4\%Mo have been selected, replacing the AISI 316L, 321 and 347 grades. Mo addition increases the resistance to naftenic corrosion. Some applications of AISI 317L steel in oil refineries are clads, vessels, tubes, valves and accessories. For some of

*e-mail: hfarneze@cefet-rj.br these applications the service temperature can reach $550{ }^{\circ} \mathrm{C}$ or higher.

The increase of $\mathrm{Cr}$, Mo and $\mathrm{Si}$ and other ferritizing elements accelerates the precipitation of $\sigma$ phase. The precipitation via $\delta$-ferrite is more rapid because this phase is $\mathrm{Cr}$, Mo and $\mathrm{Si}$ enriched, and also because the diffusion coefficients in the bcc phase are much higher than in the fcc austenite 5 . As consequence, weld metals and cast pieces of conventional austenitic stainless steels are more susceptible to $\sigma$ phase precipitation than base metals, since a higher amount of $\delta$ ferrite is usually found in the as cast structure.

Friction stir welding (FSW) is a relatively new welding processes used to join plates and tubes. This process is a solid state bonding producing a weld by applying a compressive force associated with high contact speed. Heat is generated in the welding interface due to the continuous friction of the contact surfaces, which, in turn, causes a temperature increase and later softening of the material ${ }^{5}$. Under controlled conditions, the material at the interface begins to flow plastically and provides a mixture of both faces of the base metal allowing their union. The welded material exhibits four regions, differentiated by the type of influence received in welding (Figure 1). They are the Stirred Zone, Thermomechanically Affected Zone (TMAZ), the Heat Affected Zone (HAZ) and Base Metal (BM). The stirred zone is the region through which passed the pin and mixed deformed material, which presents a complete 


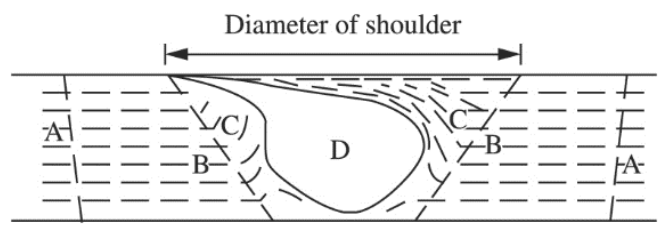

Figure 1. Schematic cross-section of a typical FSW weld showing four distinct zones: (A) base metal, (B) heat affected zone, (C) thermomechanically affected zone and (D) stirred zone.

recrystallization with a high degree of grain refinement due to the high levels of rate deformation at high temperatures, also called Zone of Dynamic Recrystallization ${ }^{6,7}$. The weld metal produced by conventional arc welding processes usually present more delta ferrite in the weld metal than obtained by FSW.

Although some previous works have predicted structural and properties changes on AISI 316/316L steel subjected to aging $^{8-10}$, very few articles were published with AISI 317L. On the other hand, compared to conventional fusion welding processes that are routinely used for weld stainless steels, friction stir welding (FSW) is an emergent process from weld in the solid state. The recent studies of its application to austenitic steels exhibit satisfactory results, such as the reduction or absence of deleterious phases ${ }^{6,11,12}$. In this work, the influence of long term exposition on the microstructure and corrosion properties of the stirred zone of a welding joint of AISI 317L steel produced by FSW was investigated.

\section{Experimental Procedures}

The welded joint was performed using plates in AISI 317L austenitic stainless steel with dimensions $655 \mathrm{~mm} \times 100 \mathrm{~mm} \times 6 \mathrm{~mm}$. Table 1 shows the chemical composition of stainless steel studied, according to the manufacturer.

The welded joint was produced by a Friction Stir Welding Machine TTI RM-2 (Transformation Technologies Inc.) located at Brazilian Nanotechnology National Laboratory. The welding tool was composed by PCBN (Polycrystalline Cubic Boron Nitride) (60\%vol.) and W-Re alloy (40\%vol.).

Welding parameters are presented in Table 2. The average welding energy (Es) was calculated from Equations 1 and 2 shown below:

$\mathrm{P}=\frac{(2 \pi) \Omega \mathrm{T}}{60}$

$\mathrm{E}_{\mathrm{S}}=\frac{\mathrm{P}}{\mathrm{V}}$

Where $\mathrm{P}$ is the power of the process $(\mathrm{kW}), v$ the forward speed of the tool ( $\mathrm{mm} / \mathrm{s}), \Omega$ the rotation speed of the tool (rpm), and T average torque recorded in the process (N.m) ${ }^{13}$.

After welding, specimens from the welded joint and base metal were aged at $550{ }^{\circ} \mathrm{C}$ for $200 \mathrm{~h}, 300 \mathrm{~h}$ and $400 \mathrm{~h}$, with subsequent cooling in water.

The microstructures were analyzed by scanning electron microscopy (SEM) and energy dispersive X-ray spectroscopy (EDS). The delta ferrite content $(\delta)$ of base metal and stirred zone were also measured using a Fisher Helmut ferritoscope. Thermocalc ${ }^{\circledR}$ simulation with Steel / Fe - alloys v 6.0 modulus and TCFE6 database was used to predict the phases more stable at $550{ }^{\circ} \mathrm{C}$.
Table 1. Chemical composition of the base metal (wt\%). (Fe) balance.

\begin{tabular}{lcccccccc}
\hline Material & $\mathbf{C}$ & $\mathbf{M n}$ & $\mathbf{S i}$ & $\mathbf{S}$ & $\mathbf{P}$ & $\mathbf{C r}$ & $\mathbf{N i}$ & $\mathbf{M o}$ \\
\hline AISI 317L & 0.024 & 1.34 & 0.47 & 0.003 & 0.031 & 18.13 & 11.41 & 3.02 \\
\hline
\end{tabular}

Table 2. Parameters used for welding and welding of medium energy.

\begin{tabular}{cc}
\hline \multicolumn{2}{c}{ FSW Process } \\
\hline Penetration (\%) & 93.3 \\
Speed of Advance (mm/min) & 100 \\
Rotation Speed (rpm) & 364 \\
Averange Torque (N.m) & 81 \\
Es (kJ/mm) & 1.8 \\
\hline
\end{tabular}

The degrees of sensitization of all specimens were evaluated by the double loop electrochemical polarization reactivation (DL-EPR) tests, as described by Čihal ${ }^{14}$. A three electrode cell was used, with working electrode of the specimen tested, saturated calomel electrode (SCE) as reference, and a $\mathrm{Pt}$ wire as counter electrode. The electrolyte was a $2 \mathrm{MH}_{2} \mathrm{SO}_{4}+0.01 \mathrm{MKSCN}$ solution at room temperature. The tests were initiated when steady state open circuit potential (OCP) was stabilized (about $30 \mathrm{~min}$ ) followed by the potential sweep in the anodic direction at $1 \mathrm{mVs}^{-1}$ until the potential of $0.3 \mathrm{~V}_{\mathrm{SCE}}$ was reached, then the scan was reversed to the cathodic direction until the OCP. An activation loop is observed in the anodic sweep due to the passivation of the steel. If a second loop is observed in the reverse sweep, called activation loop, it means that the material has $\mathrm{Cr}$-depleted áreas. The magnitude of the second loop is proportional to the Cr-depleted área. Thus, the loss of corrosion resistance due to the chromium-depleted regions, i.e. the degree of sensitization, was evaluated from the ratio $\mathrm{Ir} / \mathrm{Ia}$, where Ia is the activation peak current of the anodic scan and Ir is the reactivation peak current of the reverse scan.

The main response of the DL-EPR test is the degree sensitization, expressed by the Ir/Ia ratio, where Ir is the peak current in the reactivation loop and Ia is the peak current in the activation loop.

\section{Results and Discussion}

Figures 2a, 3a, 4a and 5a show the microstructures from the Stirred Zone of specimens un-aged, and aged for $200 \mathrm{~h}$, $300 \mathrm{~h}$ and $400 \mathrm{~h}$, respectively. Figures $2 \mathrm{~b}, 3 \mathrm{~b}, 4 \mathrm{~b}$ and $5 \mathrm{~b}$ show the DL-EPR curves of the same specimens of Figures 2-5a. The preparation of specimens for SEM included grinding and careful polishing till $1 \mu \mathrm{m}$ diamond paste. The images were obtained in the SEM operating in the backscattered electron mode (BSE). The contrast between the phases is obtained due to the differences of chemical composition. Mo-rich phases appear more bright because Mo is heavier than $\mathrm{Cr}$ and $\mathrm{Ni}$.

Table 3 shows the results of chemical composition determined by Energy Dispersive Spectroscopy (EDS) from selected points in Figure $2 \mathrm{a}$. The ferrite $(\delta)$ and austenite $(\gamma)$ phases were identified. As expected, ferrite is slightly richer in $\mathrm{Cr}$ and $\mathrm{Mo}$, and austenite in the Ni-enriched. Intermetallic phases were not identified in the as welded condition. The DL-EPR curve (Figure 2a) is typical from a non-sensitized material, with $\mathrm{Ir} / \mathrm{Ia}$ very low and equal 0.001 . 
Tables 4, 5 and 6 show the chemical composition obtained by EDS of points selected in Figures 3a, 4a and 5a, respectively. Although an individual particle could not be analyzed without the influence of the matrix, there is evidence of intermetallic phases (IP) precipitation in the points where the $\mathrm{Cr}$ and Mo contents were higher than found in the ferrite phase. These $\mathrm{Cr}$ and Mo rich regions increased with aging time, as expected.

As observed, in the AISI $317 \mathrm{~L}$, the intermetallic phase precipitation is mainly concentrated in the delta ferrite islands $(\delta)$, being a result of decomposition reactions such as $\delta \rightarrow \mathrm{Fe}_{2} \mathrm{Mo}, \delta \rightarrow \chi, \delta \rightarrow \sigma$ and/or $\delta \rightarrow \gamma+\sigma$. Since sigma $(\sigma)$, chi $(\chi), \mathrm{Fe}_{2} \mathrm{Mo}$ and austenite $(\gamma)$ are paramagnetic phases, the measurement of ferrite volumetric percentages by magnetic methods may give addition information about the intermetallic precipitation. Figure 6 shows the variation of ferrite volume fraction with aging time for base metal and stirred zone. Comparing the un-aged specimens, it can be concluded that the heating and deformation produced during FSW caused the reduction of the ferrite content from $4.6 \%$ to $2.3 \%$. In both cases, the prolonged aging at $550{ }^{\circ} \mathrm{C}$ provokes the reduction of the ferrite content, corroborating the features observed by SEM, i.e., the intermetallic phase

Table 3. Chemical composition analyzed by EDS of points selected in Figure 2a (wt.\%).

\begin{tabular}{cccrccc}
\hline Points & Fe & Cr & \multicolumn{1}{c}{ Ni } & Mo & Si & Phase \\
\hline 1 & 66.57 & 17.99 & 10.25 & 3.05 & 0.65 & $\gamma$ \\
2 & 64.78 & 21.48 & 7.15 & 4.51 & 0.65 & $\delta$ \\
3 & 64.85 & 21.32 & 6.70 & 4.90 & 0.96 & $\delta$ \\
4 & 65.48 & 20.04 & 8.15 & 4.22 & 0.79 & $\delta$ \\
\hline
\end{tabular}

Table 4. Chemical composition of the points identified by EDS in Figure $3 \mathrm{a}(\mathrm{wt} \%)$.

\begin{tabular}{cccrccc}
\hline Points & Fe & Cr & \multicolumn{1}{c}{ Ni } & Mo & Si & Phase \\
\hline 1 & 64.98 & 17.45 & 12.38 & 2.98 & 0.73 & $\gamma$ \\
2 & 63.64 & 20.11 & 8.76 & 4.66 & 1.19 & $\delta$ \\
3 & 64.21 & 19.86 & 9.24 & 4.44 & 0.85 & $\delta$ \\
4 & 64.09 & 22.32 & 6.23 & 5.44 & 0.71 & IP \\
\hline
\end{tabular}

precipitation. The reduction of the \%ferrite can be roughly related to the amount of intermetallic phase precipitated.

Figure 7 shows the ferrite island decomposed in a specimen of base metal aged for $400 \mathrm{~h}$. Figure 8 compares the evolution of the degree of sensitization with aging time base metal and stirred zone. The effects of precipitation are similar for both regions, i.e. the degree of sensitization increases due to the precipitation. A considerable difference is observed in the specimens aged for $400 \mathrm{~h}$. The stirred zone is less sensitized because its ferrite content is lower and, consequently, the amount of intermetallic phases precipitated must be inferior to the base metal.

As pointed out, the precipitates formed at $550{ }^{\circ} \mathrm{C}$ were so fine that could not be identified by SEM/EDS analysis. According to computational thermodynamic analysis carried out with Thermocalc (Figure 9) the intermetallic phases in equilibrium at $550{ }^{\circ} \mathrm{C}$ are $\chi, \sigma$, and $\mathrm{Cr}$ carbides. However, Yang \& Busby ${ }^{15}$ have found by thermodynamic calculation that Laves phase $\left(\mathrm{Fe}_{2} \mathrm{Mo}\right)$ was also prone to precipitate among with $\sigma, \delta, \chi$ and $\mathrm{M}_{23} \mathrm{C}_{6}$ in an AISI 316 stainless steel with $2.33 \% \mathrm{Mo}$ and $16.6 \% \mathrm{Cr}$ treated at $550{ }^{\circ} \mathrm{C}$. An interesting review about the possible precipitation reactions that can occur in austenitic stainless steels is presented by

Table 5. Chemical composition of the points identified by EDS in Figure $4 \mathrm{a}(\mathrm{Wt} \%)$.

\begin{tabular}{ccccccc}
\hline Points & Fe & Cr & Ni & Mo & Si & Phase \\
\hline 1 & 65.37 & 18.37 & 11.18 & 3.09 & 0.63 & $\gamma$ \\
2 & 65.90 & 20.89 & 8.01 & 3.16 & 0.79 & $\delta$ \\
3 & 61.97 & 21.67 & 8.45 & 5.75 & 0.83 & IP \\
4 & 63.36 & 22.19 & 6.73 & 5.56 & 0.80 & IP \\
\hline
\end{tabular}

Table 6. Chemical composition of the points identified by EDS in Figure 5a (wt $\%)$.

\begin{tabular}{ccccccc}
\hline Points & Fe & Cr & Ni & Mo & Si & Phase \\
\hline 1 & 65.46 & 17.99 & 11.03 & 3.11 & 0.82 & $\gamma$ \\
2 & 65.34 & 20.85 & 7.86 & 3.71 & 0.82 & $\delta$ \\
3 & 62.70 & 20.27 & 9.64 & 4.95 & 0.94 & $\delta$ \\
4 & 62.81 & 21.95 & 6.97 & 5.89 & 0.88 & IP \\
\hline
\end{tabular}

(a)

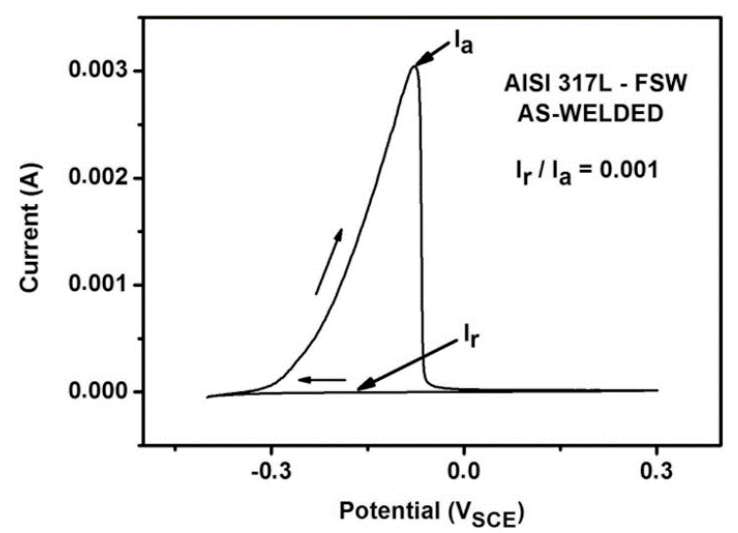

(b)

Figure 2. (a) Microstructure and (b) DL-EPR curve of specimen as welded. 


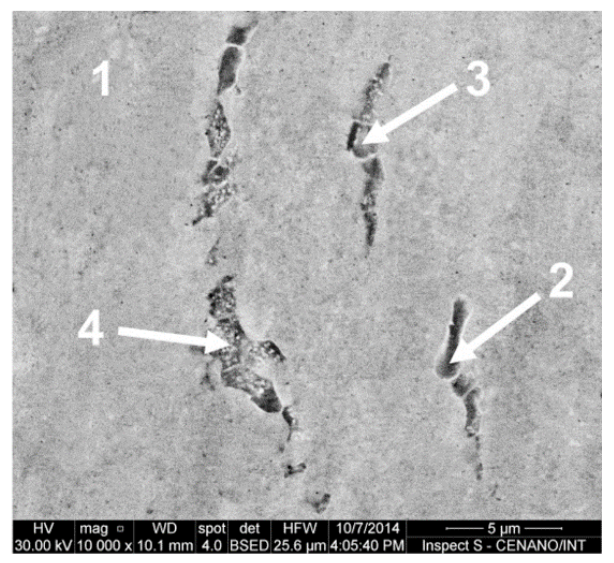

(a)

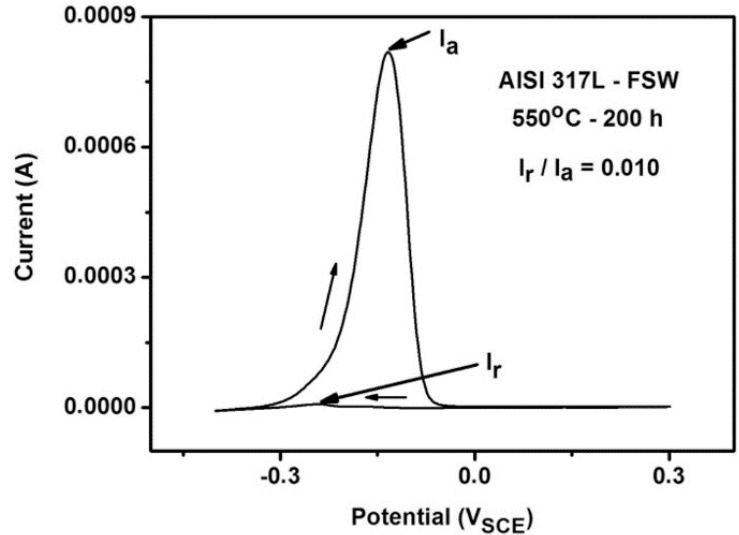

(b)

Figure 3. (a) Microstructure and (b) DL-EPR curve of specimen aged at $550^{\circ} \mathrm{C}$ for $200 \mathrm{~h}$.

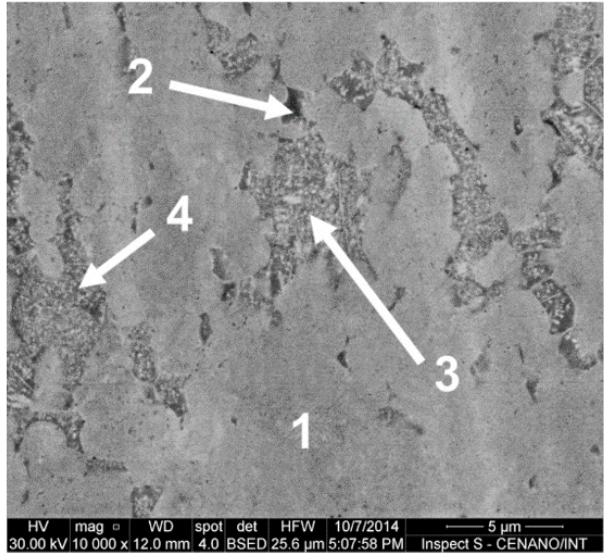

(a)

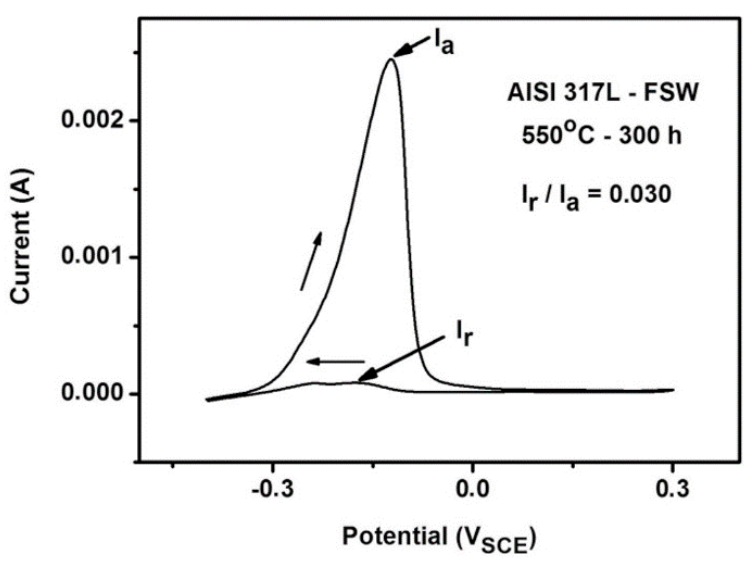

(b)

Figure 4. (a) Microstructure and (b) DL-EPR curve of specimen aged at $550{ }^{\circ} \mathrm{C}$ for $300 \mathrm{~h}$.

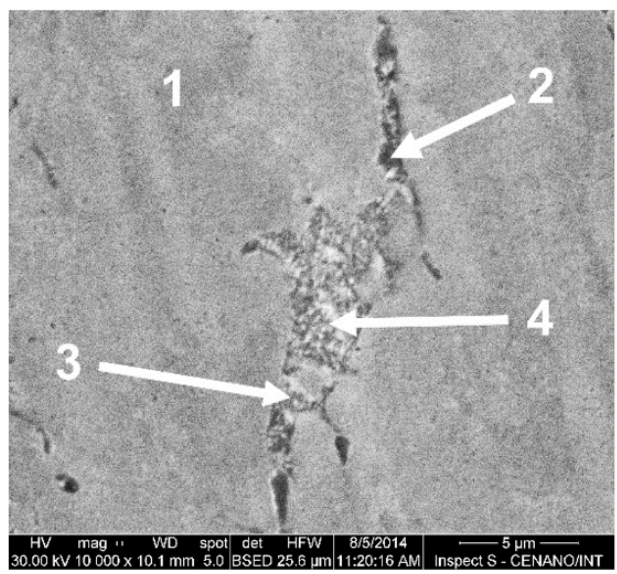

(a)

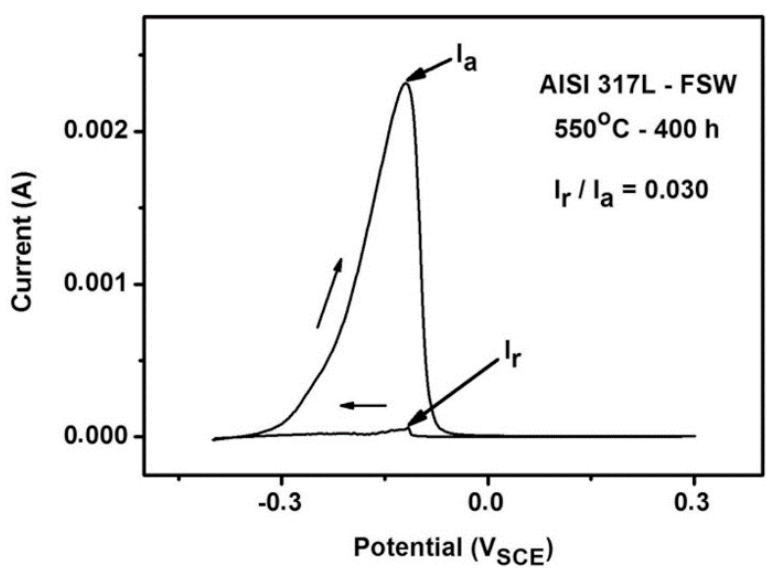

(b)

Figure 5. (a) Microstructure and (b) DL-EPR curve of specimen aged at $550{ }^{\circ} \mathrm{C}$ for $400 \mathrm{~h}$. 


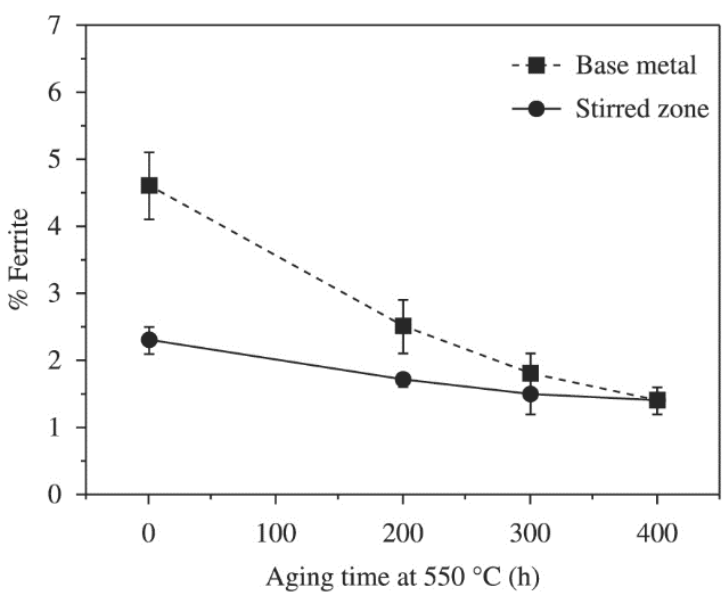

Figure 6. Variation of the amount of ferrite with aging time at $550{ }^{\circ} \mathrm{C}$.

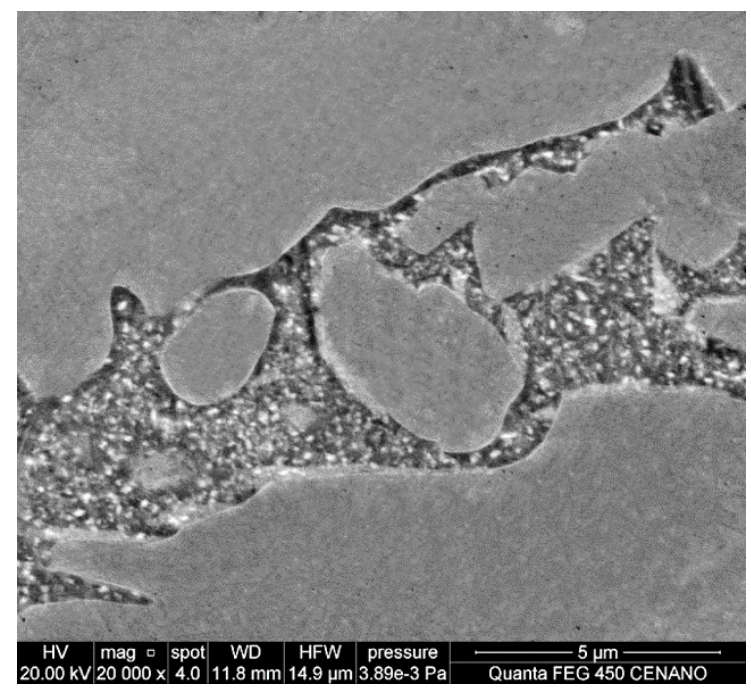

Figure 7. Base metal aged at $550{ }^{\circ} \mathrm{C}$ for $400 \mathrm{~h}$.

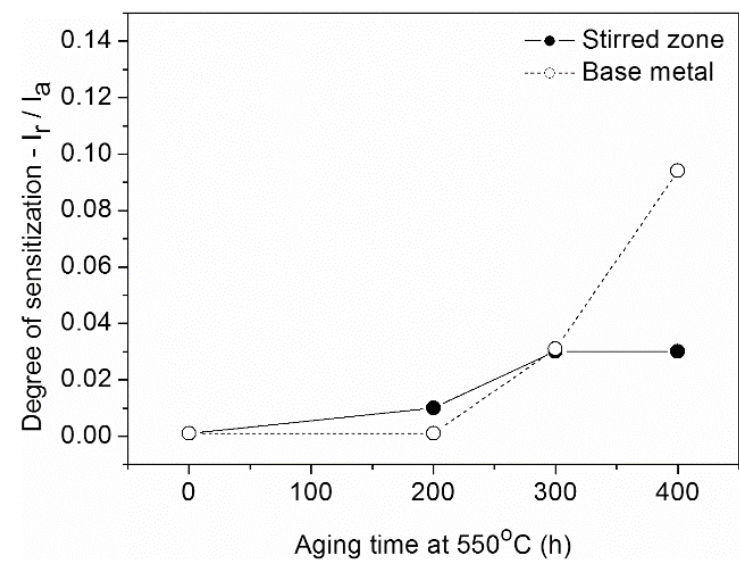

Figure 8. Evolution of the degree of sensitization with aging time at $550{ }^{\circ} \mathrm{C}$ for base metal and stirred zone.

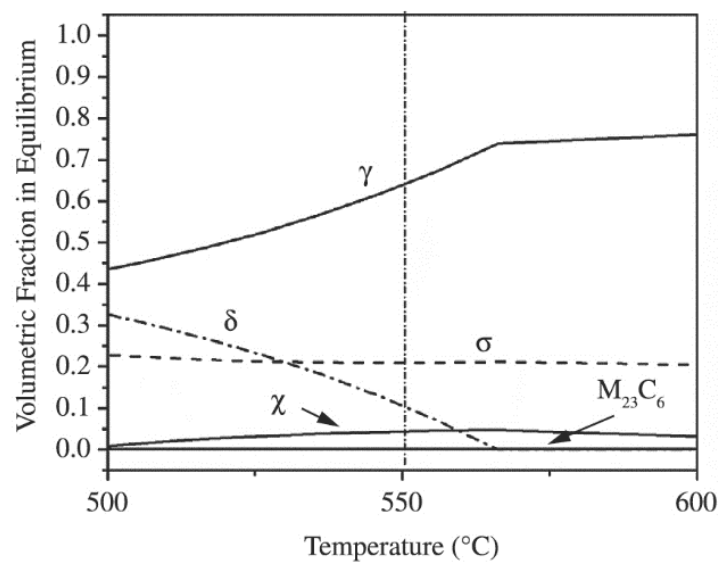

Figure 9. Equilibrium volume fraction of phases in equilibrium in the AISI $317 \mathrm{~L}$ steel with the composition of Table 1.

Plaut et al. ${ }^{10}$. In their work, a specimen of AISI 316 tested in creep at $550{ }^{\circ} \mathrm{C}$ for $85000 \mathrm{~h}$ showed the austenite islands decomposed into austenite plus sigma. Intergranular sigma was found to precipitate from austenite. However, that is a stage of aging much more advanced that observed in this work, were the maximum aging time was $400 \mathrm{~h}$. The fine particles precipitated uniformly into the ferrite islands (Figures 4a, 5a and 7) must be from a phase precursor to $\sigma$. Considering the precipitation from the ferrite phase, the two possible phases are $\mathrm{Fe}_{2} \mathrm{Mo}$ and $\chi$. In the case of precipitation from austenite in the grain boundaries the precursor phase is the $\mathrm{Cr}_{23} \mathrm{C}_{6}$ chromium carbide ${ }^{16}$.

\section{Conclusions}

The present study aimed to characterize the base metal and stirred zone of weld metal produced by friction stir welding (FSW). The effects of aging at $550{ }^{\circ} \mathrm{C}$ for times up to 400 hours on the microstructure and sensitization were also investigated. The main conclusions of this study are:

- The stirred zone in the as-welded condition did not show the presence of intermetallic phases. Besides, its delta ferrite content $(2.3 \%)$ was lower than measured in the base metal $(4.6 \%)$.

- In the specimens aged at $550{ }^{\circ} \mathrm{C}$ up to $400 \mathrm{~h}$, fine Intermetallic precipitates uniformly distributed in the ferrite islands were observed by SEM. The ferrite content decreased gradually with the increase of aging time, as consequence of the progress of the progress of precipitation.

- The fine precipitates observed within $400 \mathrm{~h}$ of aging were from $\mathrm{Cr}$ and $\mathrm{Mo}$ rich phases precursor to sigma $(\sigma)$.

- The degree of sensitization measured by DL-EPR tests increased with aging time at $550{ }^{\circ} \mathrm{C}$, as consequence of intermetallic phase precipitation.

\section{Acknowledgements}

Authors acknowledge the Brazilian Research Agencies CAPES and CNPq for financial support. 


\section{References}

1. Della Rovere CA, Castro-Rebello M and Kuri SE. Corrosion behavior analysis of an austenitic stainless steel. Engineering Failure Analysis. 2013; 31:40-47. http://dx.doi.org/10.1016/j. engfailanal.2013.01.044.

2. Farrar JMC and Marshall AW. Type " $300 \mathrm{H}$ " austenitic stainless steel weld metals for high-temperature service. In: Proceedings of Stainless Steel World 99 Conference; 1999. The Hague: KCI Publishing BV; 1999. p. 147-162.

3. Guan K, Xu X, Xu H and Wang Z. Effect of aging at 700 ${ }^{\circ} \mathrm{C}$ on precipitation and toughness of AISI321 and AISI 347 austenitic stainless steel welds. Nuclear Engineering and Design. 2005; 235(23):2485-2494. http://dx.doi.org/10.1016/j. nucengdes.2005.06.006.

4. Källqvist J and Andrén HO. Microanalysis of a stabilised austenitic stainless steel after long term ageing. Materials Science and Engineering. 1999; 270(1):27-32. http://dx.doi. org/10.1016/S0921-5093(99)00234-8.

5. Padilha AF, Escriba DM, Materna-Morris E, Rieth M and Klimenkov M. Precipitation in AISI 316L(N) during creep tests at 550 and $600{ }^{\circ} \mathrm{C}$ up to 10 years. Journal of Nuclear Materials. 2007; 362(1):132-138. http://dx.doi.org/10.1016/j. jnucmat.2006.12.027.

6. Mishra RS and Ma Z. Friction stir welding and processing. Materials Science and Engineering. 2005; 50(1-2):1-78. http:// dx.doi.org/10.1016/j.mser.2005.07.001.

7. Nandan R, Debroy T and Bhadeshia HKDH. Recent advances in friction-stir welding - process, weldment structure and properties. Progress in Materials Science. 2008; 53(6):9801023. http://dx.doi.org/10.1016/j.pmatsci.2008.05.001.

8. Yang Y and Busby JT. Thermodynamic modeling and kinetics simulation of precipitate phases in AISI 316 stainless steels. Journal of Nuclear Materials. 2014; 448(1-3):282-293. http:// dx.doi.org/10.1016/j.jnucmat.2014.02.008.
9. Sahlaoui $\mathrm{H}$ and Sidhom H. Experimental investigation and analytical prediction of $\sigma$-phase precipitation in AISI 316L austenitic stainless steel. Metallurgical and Materials Transactions A. 2013; 44(7):3077-3083.

10. Plaut RL, Herrera C, Escriba DM, Rios PR and Padilha AF. A short review on wrought austenitic stainless steels at high temperatures: processing, microstructure, properties and performance. Materials Research. 2007; 10(4):453-460. http:// dx.doi.org/10.1590/S1516-14392007000400021.

11. Park SHC, Sato YS, Kokawa H, Okamoto K, Hirano S and Inagaki M. Corrosion resistance of friction stir welded 304 stainless steel. Scripta Materialia. 2004; 51(2):101-105. http:// dx.doi.org/10.1016/j.scriptamat.2004.04.001.

12. Chen YC, Fujii H, Tsumura T, Kitagawa Y, Nakata K, Ikeuchi $\mathrm{K}$, et al. Banded structure and its distribution in friction stir processing of 316L austenitic stainless steel. Journal of Nuclear Materials. 2012; 420(1-3):497-500. http://dx.doi.org/10.1016/j. jnucmat.2011.10.053.

13. Wei LY and Nelson TW. Correlation of microstructures and process variables in FSW HSLA-65 steel. Welding Journal. 2011; 90:95-101.

14. Čihal V and Štefec R. On the development of the electrochemical potentiokinetic method. Electrochimica Acta. 2001; 46(2425):3867-3877. http://dx.doi.org/10.1016/S0013-4686(01)00674-0.

15. Yang Y and Busby JT. Thermodynamic modeling and kinetics simulation of precipitate phases in AISI 316 stainless steels. Journal of Nuclear Materials. 2014; 448(1-3):282-293. http:// dx.doi.org/10.1016/j.jnucmat.2014.02.008.

16. Pardal JM, Carvalho SS, Barbosa C, Montenegro TR and Tavares SSM. Failure analysis of AISI 310 S plate in an inert gas generator used in off-shore oil platform. Engineering Failure Analysis. 2011; 18(6):1435-1444. http://dx.doi.org/10.1016/j. engfailanal.2011.04.005. 